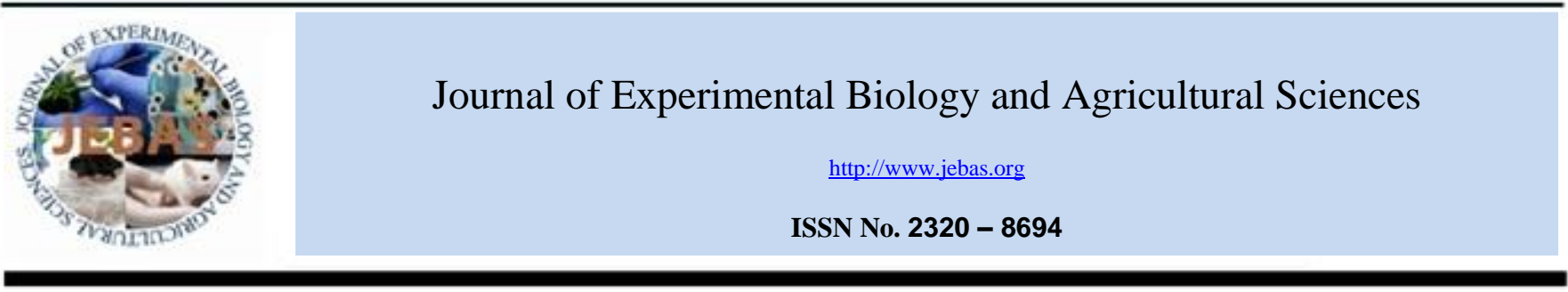

\title{
NUTRITIVE EVALUATION OF AZOLLA AS LIVESTOCK
}

\section{FEED}

\section{Anitha KC ${ }^{*}$, Rajeshwari YB, Prasanna SB and Shilpa Shree J}

Department of Livestock Production and Management, Veterinary College, Bengaluru- 560024

Received - October 20, 2016; Revision - November 03, 2016; Accepted - November 06, 2016

Available Online - November 13, 2016

DOI: http://dx.doi.org/10.18006/2016.4(Issue6).670.674

\section{KEYWORDS}

Azolla

Proximate Analysis

Chemical composition

Livestock

Fee

Evaluation

ABSTRACT

Present study was undertaken to explore the nutritive potential of Azolla pinnata as an animal feed. For this Azolla was cultivated in water trough, harvested and sundried. Sundried Azolla sample was analysed for proximate principles. The dry matter content of azolla was 4.7 percent. Analysis of dry matter revealed the presence of total 82.66 percent organic matter. Among these includes 22.48 percent crude protein, 4.5 percent ether extract, 14.7 percent crude fiber, and 40.98 percent nitrogen free extract. The total Ash content was17.34 percent.The chemical analysis proves that azolla is a rich source of crude protein, trace minerals and vitamins. The mineral profile of Azolla indicates $1.64 \%$ Calcium, $2.71 \%$ Potassium and $0.34 \%$ Phosphorus and other minerals in trace levels. Thus Azolla can be considered as potential unconventional feed for livestock.
\end{abstract}

Dry matter
* Corresponding author

E-mail: anithakcmallik@gmail.com(Anitha KC)

Peer review under responsibility of Journal of Experimental Biology and Agricultural Sciences.

Production and Hosting by Horizon Publisher India [HPI] (http://www.horizonpublisherindia.in/).

All rights reserved
All the article published by Journal of Experimental Biology and Agricultural Sciences is licensed under a Creative Commons Attribution-NonCommercial 4.0 International License Based on a work at www.jebas.org.

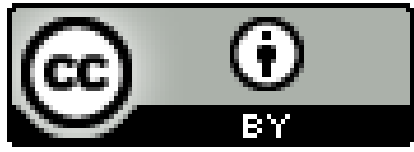




\section{Introduction}

Azolla is an aquatic free floating fern belonging to the family Salviniaceae. Nutritive value of Azolla is well documented which shows that it is a good source of protein with almost all essential amino acid required for animal nutrition (notably lysine). Furthermore, it also provides macronutrients like calcium, magnesium, potassium and vitamins like vitamin A (precursor beta-carotene) and B12. All these facts suggested that Azolla can be used as unconventional feed with protein supplement for many species including ruminants, poultry, pigs and fish (Hossiny et al., 2008). Due to ease of cultivation, high productivity and good nutritive value it is used as a beneficial fodder supplement by various researchers (Singh \& Subudhi, 1978; Prabina \& Kumar, 2010).

Azolla pinnata tried as a feed for broiler chicken (Alalade \& Iyayi, 2006; Balaji et al., 2009; Dhumal et al., 2009; Bolka, 2011), goats (Samanta \& Tamang, 1993) and buffalo calves (Indira et al., 2009). Azolla filiculoides was also used in diets for sows (Leterme et al., 2010) and as partial replacement of protein source for growing fattening pigs (Duran, 1994; Becerra et al., 1995). Furthermore, it was also tried as a protein supplement for Rabbits (Gualtieri et al., 1988; Wittouk et al., 1992, Sreemannaryana et al., 1993; Abdella et al.,1998; Sadek et al., 2010). In view of the above facts, the present experiment, the nutritional value of Azolla pinnata was undertaken.

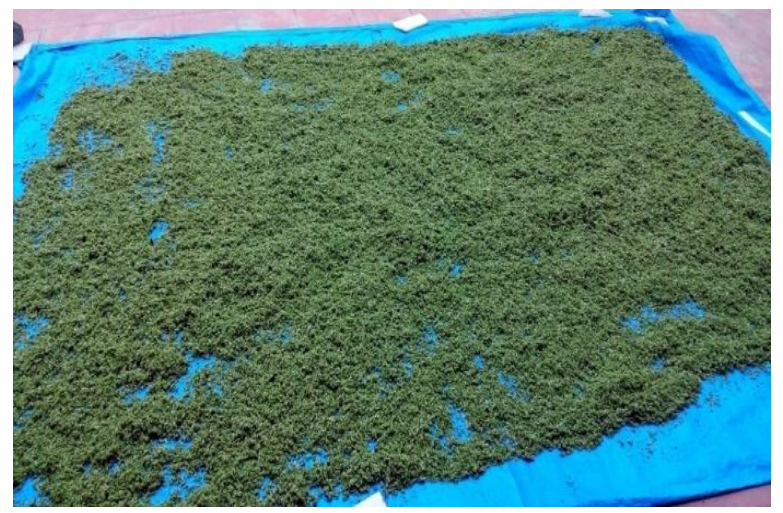

Plate 1: Sun drying of azolla.

\section{Materials and Methods}

Present study has been carried out at the department of Livestock Production and Management, Bangalore Veterinary College, Karnataka

\subsection{Cultivation of Azolla in Water Troughs}

Three water troughs with even bottom and 10 sft. capacity were taken for the study. All the roots and other unwanted particles were removed from the floor and sealed the bottom with cement and the same level in order to maintain a uniform water level. Any thin layer of $10-15 \mathrm{~cm}$ made up of fine soil were spread and then, the water tank filled with water and maintain the constant level of the water. About $1.5 \mathrm{~kg}$ of cow dung dissolves in 3.5 liters of water and spread evenly in the water trough. Preparation once completed, the water tank injected with fresh azolla culture of $300 \mathrm{~g} / \mathrm{m}^{2}$ on it. Once in every 15 days, application of $1.5 \mathrm{~kg}$ dung, $0.2 \mathrm{~g}$ super phosphate and $0.2 \mathrm{~g}$ of mineral mixture was done to obtain continuous growth of azolla and to avoid nutrient deficiency and also check the $\mathrm{pH}$. In the case of pits contaminate with insects and contaminates, a fresh pure culture was added.

\subsection{Collections and storage of azolla}

Azolla multiplied rapidly and covered the complete pits within 7 days. Fully grown azolla (Plate 2) was harvested every week from the water trough. Harvesting azolla was cleaned and thoroughly washed and sundried for 2-3 days and dried till crispy dried and stored in air tight aluminium foils.

Table 1 Chemical composition of azolla.

\begin{tabular}{|lc|}
\hline Nutrients & Azolla \\
\hline Dry matter & 4.70 \\
\hline Organic matter & $\mathbf{8 2 . 6 6}$ \\
\hline Crude Protein & 22.48 \\
\hline Ether extract & 4.50 \\
\hline Crude fibre & 14.70 \\
\hline Total ash & 17.34 \\
\hline NFE & 40.97 \\
\hline NDF & 54.85 \\
\hline ADF & 36.57 \\
\hline ADL & 24.05 \\
\hline
\end{tabular}

\subsection{Chemical evaluation of azolla}

The DM content of collected azolla samples were analysed by drying to a constant weight in a forced hot air oven at $105^{\circ} \mathrm{C}$. The ash content in the samples was estimated as residue after incineration of samples at $600^{\circ} \mathrm{C}$ for 3 hours. Crude protein $(\mathrm{N}$ $X$ 6.25) was analysed using Gerhardt digestion and distillation unit (AOAC, 2005). The Ether extract (EE) content in the sample was analysed after extraction with petroleum ether using the procedure of AOAC (2005). The fiber fractions were determined according to the methods described by Van Soest et al. (1991). Mineral profile of Azolla was analysed by inductively coupled plasma-atomic emission spectrophotometer and amount was calculated by below given formula.

$\mu \mathrm{g} / \mathrm{g}=$

Concentration of mineral in sample solution (mg / L) $\mathrm{x}$ Volume made $(\mathrm{ml}) /$ Weight of sample $(\mathrm{g})$ 


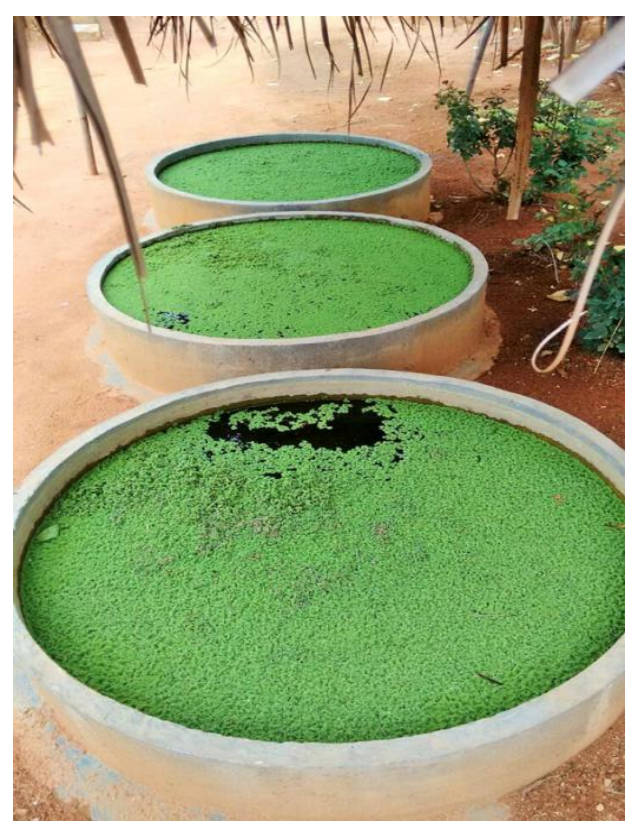

Plate 2 Azolla (Azollapinnata) grown in water trough

Parameters were analyzed by analysis of variance with using GraphPad Prism version 5.1. Individual differences between means were tested using Tukey's Multiple Comparison Test when treatment effect was significant.

\section{Results and Discussion}

The results of proximate analysis of sun dried azolla (Plate 1) sample are presented in the Table 1.The values were Total dry matter 4.7 per cent, 82.66 per cent of the organic matter, 22.48 per cent crude protein, 4.5 percent of the ether extract, 14.7 per cent of crude fiber, 17.34 percent of total ash and 40.98 per cent of nitrogen free extract.

The chemical composition of sun dried azolla as presented in the table 2 revealed that dry matter content was 4.7 which are in agreement with the findings of Giridhar et al. (2012) and Kavya (2014) whereas, Parashuramulu et al. (2013) reported almost double (8.9\%) of DM content. Though the DM content in the fresh azolla was slightly less, but can be used as a supplement to meet the DM requirements in livestock feeds.

The result of crude protein were in agreement with the findings of Basak et al. (2002), Lukiwati et al.(2008), Prasanna et al. (2011), Bolka (2011), Chatterjee et al. (2013) and Kavya (2014), those have reported crude protein values ranged from 21.0 (Kavya, 2014) to 25.8 (Basak et al., 2002). High protein content azolla suggests that it's a potential natural protein source.

The crude fibre content was close agreement with the values obtained by Balaji et al. (2009) and Cheryl et al. (2014), respectively. On the contrary Singh \& Subudhi (1978) reported less value and it ranged between 9.1 to 13.07 percent while
Alalade \& Iyayi (2006) was reported 12.7 per cent CF. Further the higher range of $\mathrm{CF}$ values from 15.17 to 19.85 was recorded by Bolka (2011) and Kavya (2014). Slight variations in the contents of $\mathrm{CF}$ in azolla was observed in the present study, when compared to other research workers which might be due to changes in the dry matter content of azolla used for $\mathrm{CF}$ estimation.

Nitrogen-free extract obtained was comparable to the findings of Kavya (2014).The higher values 47 and 47.4 percent were observed by Samanta \& Tamang (1993) and Alalade \& Iyayi (2006) respectively.

Table 2 Mineral profile of Azollapinnata (on per cent DMB).

\begin{tabular}{|lcc|}
\hline Minerals & Percentage & Ppm \\
\hline Calcium & 1.64 & \\
\hline Phosphorus & 0.34 & \\
\hline Potassium & 2.71 & 9.1 \\
\hline Copper & 2418 \\
\hline Manganese & 325 \\
\hline Zinc & 1569 \\
\hline Iron & 8.11 \\
\hline Cobalt & 5.06 \\
\hline Chromium & 31 \\
\hline Boron & 5.33 \\
\hline Nickel & 8.1 \\
\hline Lead & 1.2 \\
\hline Cadmium & \\
\hline
\end{tabular}

Total Ash in this study were similar with values of Balaji et al.(2009), Prasanna et al.(2011), Bolka (2011), Chattereji et al. (2013) Parashuramulu et al. (2013) and Kavya (2014) whose values were in the range from 16.21 percent was reported by Prasanna et al.(2011) and 19.47 percent by Chattereji et al. (2013). Whereas Subudhi \& Singh (1978) reported 10.5015.82 percent of TA in dried azolla. The higher value (24.26) of TA was reported by Cheeryl et al. (2014) while this value was 28.7 percent were also reported by Lukiwati et al. (2008).The large variation in the values of TA in azolla might be due to mineral inputs in the ingredients added for cultivation of azolla.

From the study it was revealed that the ether extract was 4.5 percent, the results are in agreement with findings (3.38$4.41 \%$ ) of other researchers Basak et al. (2002), Balaji et al. (2009), Bolka (2011) and Kavya (2014). The lower values of 2.73 and 3.27 percent were reported by Tamang et al. (1993) and Chatterjee et al. (2013) respectively. Slight variation was observed in the content of EE can be attributed to the nutrient inputs used to cultivate the azolla.

The NDF content of azolla is in close agreement with the value reported by Parnerkar et al. (1986), Kavya (2014) but higher than the values reported by Buckingham et al. (1978), Taklimi (1990); Ali \& Leeson (1995) and Alalade \& Iyayi (2006). 
The ADF content of azolla is almost similar to the value reported by Khatun et al. (1996). The ADL content of azolla obtained in present study is almost similar to the value reported by Ramesh (2008) Kavya (2014) but higher than the value reported by Tamang et al. (1993).

The mineral profile of azolla obtained in the present study is almost similar to the values reported by Anand \& Geetha (2007), Kavya (2014). Calcium content of azolla is similar to the reports of Tamang et al. (1993). Magnesium content of azolla obtained in the present study is similar to the value reported by Alalade \& Iyayi (2006). Higher level of heavy metals like nickel, lead, cadmium was also obtained in the sample of azolla used for the present study indicating bioaccumilation of heavy metals by azolla. Padmavathiamma \& Li (2007) studied the absorption of iron, copper, cadmium, nickel, lead, zinc, manganese, and cobalt by Azolla pinnata indicating bioaccumilation of heavy metals by azolla.

Yield of Azolla was reported around $120 \mathrm{~g} / \mathrm{m}^{2} /$ day fresh weight per water trough which is similar to Duran (1994) those who reported $120-200 \mathrm{~g} / \mathrm{m}^{2} /$ day of fresh azolla production can be harvested and Gerek (2001) reported that $1122 \mathrm{~g} / \mathrm{m}^{2}$ of fresh azolla can be harvested after 15 days from the inoculation of fresh weight of $300 \mathrm{~g} / \mathrm{m}^{2}$ azolla.

Azollapinnata differences in nutrient composition may be due chemical composition of soil nutrients and also may be due to differences in environmental conditions such as respond to heat, light intensity and its resulting impact on their growth, morphology. Moreover, epiphytic algal contamination resulted in affect the chemical composition (Sanginga \& VanHove, 1989).

\section{Conclusion}

Sun dried azolla on chemical analysis showed that rich in crude protein, trace minerals and vitamins and hence it can be used as livestock feed as a unconventional feed

\section{Conflict of interest}

Authors would hereby like to declare that there is no conflict of interests that could possibly arise.

\section{Reference}

Abdella MM, El-Sayaad GAE, Ghazal FM, El-Baz TA (1998), Sundried Azolla as new feedstuff in growing rabbit diets. Egyptian Journal of Rabbit Science 8: 81-93.

Alalade OA, Iyayi EA (2006) Chemical composition and feeding value of azolla (Azollapinnata) meal for egg type chicks. International Journal Poultry Science 5: 137-141

Ali MA, Leeson S (1995) Nutritional value and aquatic weeds in the diet of poultry. World's Poultry Science Journal 50: 239251.
Anand T, Geetha NP (2007) Azolla as a Biofertilizer in Coffee Plantation. I need Coffee. Html

AOAC (2005) Official methods of analysis, 18th Edition.Association of Official Analytical Chemists, Washington.D.C.

Becerra M, Preston TR, Ogle B (1995) Effect of replacing whole boiled soya beans with azolla in the diets of growing ducks. Livestock Research for Rural Development Volume 7, Article \#26. Retrieved February 18, 2016, from http://www.lrrd.org/lrrd7/3/7.htm

Balaji K, Jalaludeen A, Richard CR, Peethambaran PA, Senthilkumar S (2009) Effect of dietary inclusion of azolla (Azolla pinnata) on production performance of Broiler chicken. Indian Journal of Poultry Science 44: 195-198

Basak B, Pramanik AH, Rahaman MS, Tarafdar SU, Roy BC (2002) Azolla (Azollapinnata) as a feed ingredient in broiler ration. International Journal of Poultry Science 1: 29-32.

Bolka PC (2011) Nutritional evaluation of Azolla (Azollapinnata) in broilers and layers. Ph.D. Thesis submitted to Karnataka Veterinary, Animal and Fisheries Sciences University, Bidar.

Buckingham KW, Ela SW, Moris JG, Goldman CR (1978) Nutritive value of the Nitrogen-fixing aquatic fern Azollafiliculoides. Journal of Agriculture and Food Chemistry 26: 1230322df-1234. DOI: 10.1021/jf60219a051.

Chatterjee A, Sharma P, Ghosh MK, Mandal M, Roy PK (2013) Utilisation of Azollamicrophylla as feed supplement for crossbred cattle. International Journal of Agriculture and Food Science Technology 4: 207-214

Cherryl DM, Prasad RMV, Rao JS, Jayalaxmi P, Kumar DS (2014) A study on the nutritive value of Azolla pinnata. Livestock Research International 2: 13-15.

Dhumal MV, Siddiqui MF, Siddiqui MBA, Avari PE (2009) Performance of broilers fed on different levels of Azolla meal. Indian Journal of Poultry Science 44 : 65-68.

Duran AO (1994) raw palm oil as the energy source in pig fattening diets and Azollafiliculoides as a substitute for soya bean meal. Livestock Research for Rural Development.Volume 6, Article \#2.Retrieved February 18, 2016, from http://www.lrrd.org/lrrd6/1/ocampo2.htm.

Giridhar K, Elangovan AV, Khandekar P, Sharangouda, Sampath KT (2012) Cultivation and use of Azolla as nutritive feed supplement for the livestock. Indian Farming 62 : 20-22.

Gualtieri M, Rapaccini S, Balloni W (1988) Effects of the inclusion of Azollafiliculoides meal in feeds for growing rabbits. Rivista di Coniglicoltura 25: 55-58. 
Gerek MN (2001) The performance of Azolla mexicana in Turkish rice field. In: Chataigner J (Ed.) The new development in rice agronomy and its effects on yield and quality in Mediterranean areas.

Hossiny H, Setoudeh M, Rokni H, Dehghanzadeh H, Cheraghcheshm M (2008). Using of silage azollain Guilan male calves nutrition. Proceedings of Third National Congress of Recycling and Reuse of Reneweable Organic Resources in Agriculture Islamic Azad University, Khorasgan branch (Isfshan) Agricultural faculty, waste and water research centre.

Indira D, Sarjan RK, Suresh J, Venugopal NK, Ravi A (2009) Azolla (Azolla pinnata) as feed supplement in Buffalo calves on Growth performance. Indian Journal of Animal Nutrition 26: $345-348$.

Kavya K (2014) Nutritional evaluation of Azolla (Azolla pinnata) and its supplementary effect on in vitro digestibility of crop residues and total mixed ration. M.V.Sc Thesis submitted to Karnataka Veterinary, Animal and Fisheries Sciences University, Bidar.

Khatun A, Ali MA, Dingle JG (1999) Comparison of the nutritive value for laying hens of diets containing azolla (Azolla pinnata) based on formulation using digestible protein and digestible amino acid versus total protein and total amino acid. Animal Feed Science Technology 81: 43-46.

Leterme P, Londono AM, Ordonez DC, Rosales A, Estrada F, Bindelle J, Buldegen (2010) Nutritive value and intake of aquatic ferns (Azolla fillicoides Lam. and Salvinia molesta Mitchell) in sows. Animal Feed Science and Technology 155: 55-64. DOI: 10.1016/j.anifeedsci.2009.10.002

Lukiwati DR, Ristiario P, Wahyuni HI (2008)Azollamicrophylla as protein source for rabbits. Organic rabbit production from forages in MERKAN WORKSHOP.

Parashuramulu S, Swain PS, Nagalakshmi D (2013) Protein fraction and in vitro digestibility of azolla in ruminants. Online Journal of Animal Feed Research 3: 129-132.

Parnerkar S, Patel JM, Bhagoji GP, PATEL AP, Dave FD (1986) Voluntary intake and nutritive value of the sun dried water fern Azolla pinnata in sheep. Indian Journal of Animal Nutrition 391: 37-39.

Prabina BJ, Kumar K (2010) DriedAzolla as a nutritionally rich cost effective and immuno-modulatory feed supplement for broilers. The Asian Journal of Animal Science 5: 20-22.

Prasanna SB, Shivakumar MC, Umashankar BC, Naveen Kumar GS, Pardeep MC, Prabhu TM (2011) Influence of feeding azolla on the performance of RAJA-2 Broiler Birds. Indian Journal Animal Production Management 27: 137-141.

Padmavathiamma PK, Li LY (2007) Phytoremediation Technology: Hyper accumulation Metals in Plants. Water, Air, and Soil Pollution 184: 105-126. DOI: 10.1007/s11270-0079401-5

Ramesh H (2008) Nutritional evaluation of Azolla (Azollapinnata) and its supplementary effect on in vitro digestibility of crop residues.M.V.Sc. Thesis submitted to Karnataka Veterinary Animal and Fisheries Sciences University, Bidar.

Sadek MF, Fatma, Ahmed G, Hanan AM, Hassanein, Marvat M, Arafa. andElham M (2010) Using of azolla silage in growing rabbits feeding. Egyptian Journal of Rabbit Science 20: $67-82$.

Sanginga N, Van Hove C(1989) Amino acid composition of azolla as affected by strain and population. Plant \& Soil 117:263-267. DOI: 10.1007/BF02220720.

Singh PK, Subudhi BPR (1978) Utilization of Azolla in poultry feed. Indian Farming 27: 37-39

Sreemannarayana O, Ramachamdraiah K, Sudarshan KM, Ramanaiah NV, Ramaprasad J (1993) Utilization of azolla as rabbit feed. Indian Veterinary Journal 70: 285-286

Subudhi BPR, Singh PK (1978) Nutritive value of the Water Fern Azolla pinnata for chicks. Poultry Science 57: 378-380. DOI: $10.3382 /$ ps.0570378.

Taklimi S (1990) Utilization of Azolla microphylla in broiler feeding. MSc. Thesis submitted to University of Agricultural Sciences, Bangalore (India)

Samantha G, Tamang Y (1993) Feeding value of azolla (Azolla pinnata) an aquatic fern in Black Bengal goats. Indian Journal Animal sciences 63:188-190.

Tamang Y, Samanta G, Chakraborty N, Mondal L (1993) Nutritive value of Azolla (Azolla pinnata) and its potentiality of feeding in goats. Environment and Ecology 10: 755-756.

Vansoest PJ, Roberttson JB, Lewis BA (1991) Methods for Dietary Fiber, Neutral Detergent Fiber, and Nonstarch Polysaccharides in Relation to Animal Nutrition. Journal Dairy Sciences 74 : 3583-3597. http://dx.doi.org/10.3168/jds.S0022-0302(91)78551-2.

Wittouck P, Detimmerman F, Petry M, Hove C, Van (1992) Azolla as a food for rabbit in Africa. Journal of Applied Rabbit Research 5: 1058-1062. 